\title{
PHANTOM BORDERS AND ELECTORAL BEHAVIOR IN POLAND HISTORICAL LEGACIES, POLITICAL CULTURE AND THEIR INFLUENCE ON CONTEMPORARY POLITICS
}

\author{
JAROSŁAW JAŃCZAK
}

With 3 figures and 2 tables

Received 05 May 2014 · Accepted 18 February 2015

\begin{abstract}
Summary: The article deals with phantom borders in electoral behavior in Poland. Being aware of the already wide literature in this field, the author tries to fill a gap existing in the research by investigating scale as a factor determining phantom borders' construction. Two historical-administrative regions, Wielkopolska and Pomorze (crossed by relict boundaries) were tested quantitatively and qualitatively. By employing double de-scaling (territorial and electoral) the author discovered that in both the macro and micro scales phantom borders are present, however, their construction and manifestation differs significantly. Consequently, this finding brings a new perspective to phantom border studies, widening the currently dominating historical perspective (with its structural and normative dimensions) by adding a new element: scale. It seems to bring a new perspective in understanding the investigated processes.
\end{abstract}

Zusammenfassung: Der Beitrag setzt sich mit Phantomgrenzen im Bereich des Wahlverhaltens in Polen auseinander. Der bereits existierenden umfangreichen Literatur zu dieser Thematik durchaus bewusst, versucht der Autor eine Forschungslücke durch Untersuchung der Skala (Mikro-/Makroebene) als vorausbestimmenden Faktor der Konstruktion von Phantomgrenzen zu schließen. Die quantitative und qualitative Untersuchung wurde in zwei historisch-administrativen Regionen, Wielkopolska und Pomorze (durchschnitten von historischen Grenzen), durchgeführt. Durch den Einsatz einer De-scalingMethode (territorial und elektoral) stellt der Autor fest, dass sowohl in der Makro- als in der Mikroebene Phantomgrenzen vorhanden sind, obgleich sie sich in ihrer Konstruktion und Artikulation bedeutend unterscheiden. Im Endeffekt eröffnet dieses Ergebnis eine neue Perspektive für Phantomgrenzen-Studien, indem die derzeit vorherrschende historische Perspektive (mit strukturellen und normativen Dimensionen) um das neue Element der Skalenebene erweitert wird.

Keywords: Political geography, Poland, phantom borders, central elections, local elections, scale change

\section{Introduction}

Phantom borders are a phenomenon present in the everyday lives of many European states. In some cases, as in Ukraine, they are violently visible in political-territorial conflict, in others, as in Romania or Slovakia, they form a part of the ethnic-political relations with their neighbor. But it is mainly Poland where - due to its complicated territorial past - the debate on old, non-existent boundaries attracts not only academics, but also politicians, commentators, businessmen and ordinary people.

The eighteenth century partitions of Poland deeply diversified its economic, political and cultural realities in the Prussian/German, Russian and

DOI: $10.3112 /$ erdkunde.2015.02.03
Austrian ${ }^{1)}$ parts. This process was additionally supplemented by post-Yalta border shifts and population resettlements. Consequently, in contemporary Poland four zones can be identified when analyzing economic indicators, cultural habits or crime rates, and also - what is especially interesting for an author who is a political scientist - political behavior (BARTKOWSKI 2002). They reflect four different historical legacies and result in contemporary political processes.

Most of the current studies on the above described phenomena apply a macro-scale perspective, by concentrating on the state, its unity or diversity. They consider Poland as a single territorial-admin-

1) The name Austrian is used for the territories belonging to the Habsburg State (Austrian Empire and after 1867 to Austria-Hungary). 
istrative unit, crossed by detectable dividing lines. Those divisions are usually regarded as being identical to the administrative divisions on the regional level (voivodship - in Polish wojewódžtwo). This leads to simplifications in the spatial-political mapping of processes analyzed. The author is, however, interested if these phenomena are noticeable on levels other than the macro level and, if so, if the pattern of political behavior remains the same. And, as a result, how are historic borders reproduced in current political life, and how are they constructed or deconstructed by the actors involved? Finally, how can the phantom borders concept be developed with the help of scale manipulation to better explain the current political landscape of investigated territorial units?

This article presents the elements of a recently conducted research using a micro-approach, by investigating regional (DONAJ 2013; GRYGO and SECLER 2010; JAŃCZAK 2010; JAŃCZAK 2013) and local units (JAŃCZAK et al. 2013). It proposes double downgrading of the investigation's scale by reducing the territorial level and election type to explore tested phenomenon. Two Polish historic-administrative regions (representing different types of historical traditions and different phantom borders) have been thus selected: Wielkopolska (Greater Poland) and Pomorze (Pomerania). Electoral behavior (understood as participation level and political preferences) in central and local voting were tested there at regional (voivodship) and county (in Polish powiat) levels, which made it possible to draw a scale-related map of the historical borders' relevance. The text is based on quantitative analyses of electoral statistics, supported by a qualitative investigation (ten interviews conducted in 2011-2012 among the regional and local political elites in various parts of the investigated regions). Analytically, the concept of de-scaling frames the investigation, similarly to boundarization and frontierization models, what results from still missing widely recognized border theory (BRUNET-JAILLY 2005; Kolossov 2005; Payan 2014) or phantom border theory, that could more convincingly serve as a framework for analysis.

\section{Phantom borders - towards conceptualiza- tion}

After the collapse of communism, a revival of border studies in the United States and Europe can be observed. Consequently the nature and transformation of borders has been intensively investigated, also including historical borders in what today are politically homogeneous states. Border scholars are looking for a border theory that shall "render explanatory and predictive models" (PAYAN $2014,1)$, assuming often that "borders are separate objects of social research" (PAAsi 2005, 668). Phantom borders are understood in this paper following their conceptualization developed within the "Phantomgrenzen" project as - "former, predominantly political borders that structure today's world (...), historical spaces [that] persist or re-emerge"(Phantomgrenzen). As the author is especially interested in political behavior, and consequently, manifestations of relict borders visible in political life, he concentrates on the influence of former political boundaries on this thematic field. The critical approach requires, however, two interventions here: answering the questions of the mutual relations between border studies and the phantom border concept, as well as defining the reasons why historical borders re-emerge.

With regard to the former, the definition and approach to phantom borders shall be placed in the wider context of border studies. The phantom border concept seems to be related to the latest developments in the field of studying borders. A conceptual development in border studies, recently redesigning the dominating approach, moved the attention of scholars towards understanding borders as social constructs. As Vladimir Kolossov remarks, a "boundary is not simply a legal institution designed to ensure the integrity of state territory, but a product of social practice, the result of a long historical and geopolitical developments, and an important symbolic marker of (...) political identity" (Kolossov 2005, 652). This political identity is an outcome of the bordering process. LADIS KRISTOF sees a boundary as a "meeting place of two sociopolitical bodies, each having its particular interests, structure, and ideology" (KRISTOF 1959, 277). Political identities on the respective border sides are structured then by various powers. Borders are seen as "participation in a collective consciousness (rituals, customs, traditions, laws, historical knowledge, and even language) associated with a particular territory" (O'DowD and WILSON 2002, 19).

This approach would mean that borders are complex phenomena of multidimensional composition. However, their transposition to phantom borders seems not to be automatic, and is not academically obvious. On the other hand, a careful investigation of already existing findings on the character of borders paves the way for a better understanding of phantom borders and their nature: they are rooted in 
political boundaries and boundarization processes both in their historical and functional aspects. This conclusion makes it possible to concentrate on the second of the above indicated questions.

With regard to the latter (reasons for the reemergence of historical borders): from the perspective of history-present day relations, actual state borders are considered to be outcomes of historical processes. They are "reminders of the past, (...) the products of previous conquests, invasions, population movements or treaties. Any redefinition or transformation of borders means engaging with the past" (O'Dowd and Wilson 2002, 8). One can assume that state borders that have disappeared are characterized by very similar features, and also in their case changing the state of art is a game with (or against) historical developments.

Functionally, as stressed by scholars, old boundaries are hardly erasable due to several reasons. As Nail Alkan points, "everywhere where borders have been removed new ones have to be created (...), keeping this in mind, borders have to be understood as boundaries enclosing a space of identification and orientation" (ALKAN 2002, 37). This happens because of the logic of the European integration, where borders devaluate (O'DowD and WILSON 2002, 10), but where, at the same time, mental (...) borders become more important (EHLERs et al. 2001, 2). Relict borders constitute one of the ways of finding differences. Additionally, state related processes contribute to the process: the more safe the state borders are, the more visible the internal divisions are (O'Dowd and WILSON 2002, 17). Consequently, any form of bordering - also with regard to old borders - seems to be the key concept for organizing political and social space. As David Newman claims, "all borders share a common function to the extent that they include some and exclude many others"(Newman 2003, 16). So one could conclude that phantom borders are (re)constructed as a form of virtual enclosure, and any "enclosure fosters a feeling of security and people prefer to live in familiar circumstances" (ALKAN 2002, 37).

At the end, it shall be emphasized that scholars engaged in phantom border research are intensively looking for theoretical support in their investigation. Among various approaches, the concept of path dependency could be mentioned (PeTERs et al. 2005), assuming that "history matters" in understating current political processes (PAGE 2006) and concentrating on relations between continuity and change in them (BOAS 2007).

\section{Political, historical, geographical and ana- lytical context}

To conduct further investigations into the Polish case, several contextual remarks have to be made, framing the analysis and settling it in the wider political, spatial and historical landscape of Poland.

First of all, the political ruptures in Poland are reflected in the ruling political options at the central level. In the 2001-2005 period, the Polish political scene was dominated by the social democrats (rooted in post-communist traditions), the SLD (Sojusz Lewicy Demokratycznej-Democratic Left Alliance). In 2005-2007 it was marked by conservative governments, PiS (Prawo i Sprawiedliwość - Law and Justice), since 2007 by liberals, PO (Platforma Obywatelska - Civic Platform). Those three political orientations have dominated the political scene both at the central and local levels in Poland.

Secondly, there is the location of the above-mentioned four zones (Fig. 1). Prussian/ German Poland (no. 1) contained three regions ((Eastern) Pomorze, Wielkopolska and Górny Slatsk - Upper Silesia) in the nineteenth century, ethnically mainly Polish at that time, but sharing a century long tradition of neighboring Germany and exposed to German influences. Russian Poland (no. 2) consisted of central and eastern regions, with the capital - Warsaw - and was also dominated by Poles and Polish culture in the nineteenth century. Austrian Poland (no. 3) was located in the southern part of the country, around Cracow, and, similarly to the previous two, being Polish in terms of culture and language. All three belonged to their respective empires in the nineteenth century. Finally, the post-German (the name applied to the lands given to Poland after the end of the Second World War) territories (no. 4) were, by 1945, ethnically and politically German. They were granted to Poland as compensation for the Polish eastern provinces which were transferred to the Soviet Union after the end of the Second World War. The German population fled and was expelled, and replaced by Polish settlers from the east (previously exposed to Russian influences).

Thirdly, the electoral map of Poland, when analyzing parliamentary and presidential voting in the last two decades, reveals territorially marked preferences. As demonstrated by subsequent election results charts (for example Fig. 2), the western and northern regions (administratively voivodships) usu- 


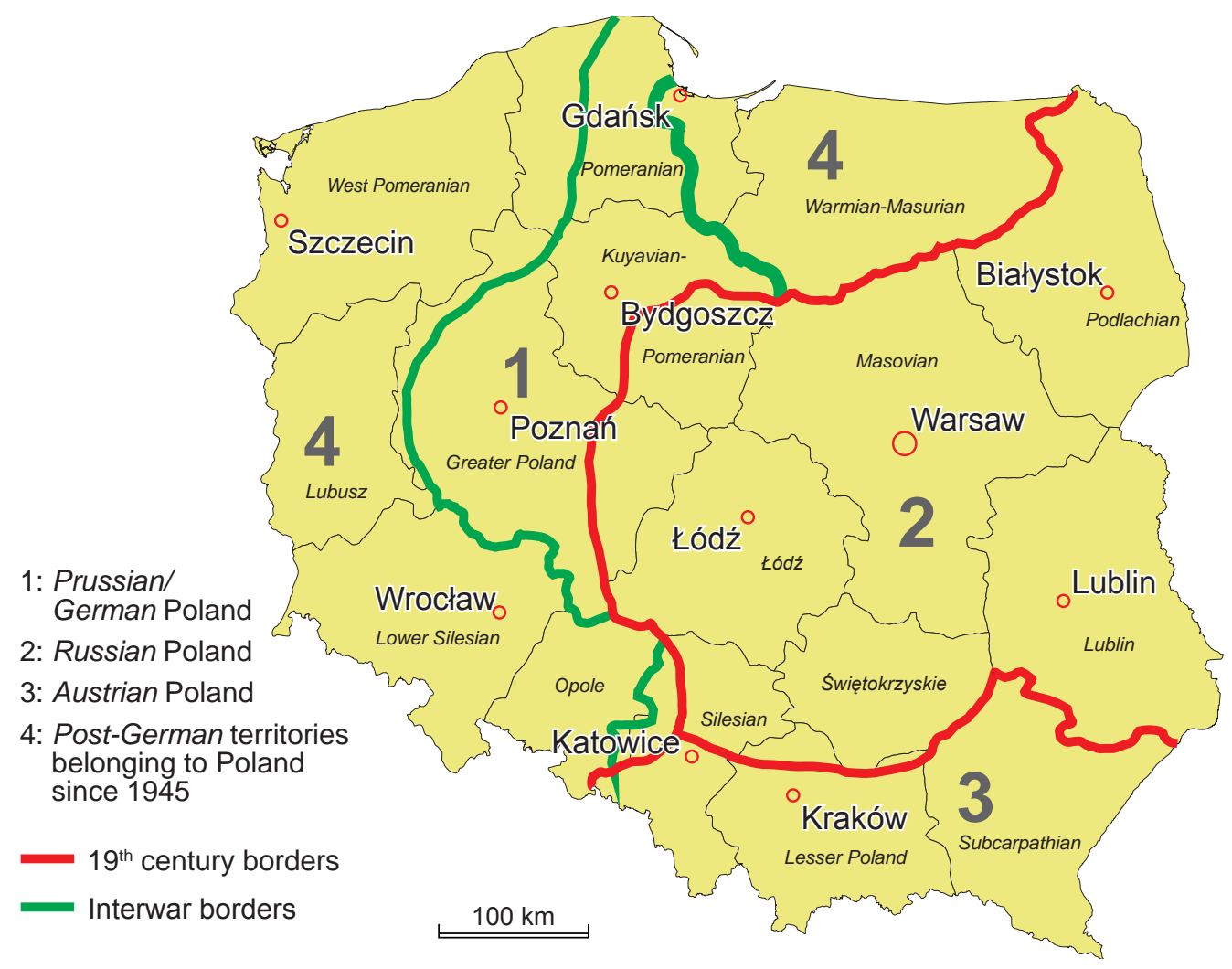

Fig. 1: Voivodeships of Poland and historical borders

ally opt for liberal/social democratic parties and candidates (so-called liberal Poland, in Polish Polska liberalna), the central and eastern provinces are dominated by conservative voters (so called solidary Poland, in Polish Polskea solidarna ${ }^{2}$ ). The borders (usually very sharp) of the indicated splits (not) surprisingly correspond with the historical borders within the Polish state: the nineteenth century boundaries of Prussia/Germany, Russia and Austria (JAnICKI et al. 2005). Additionally, post-German territories are also visible in this puzzle.

Fourthly, despite different interpretations, interdependence between historical borders and actual electoral behavior (participation level and political preferences) is widely recognized as an explanatory factor. It is related to the nineteenth century as a period of the creation of modern nations and states, with all their consequences for power structures within the states' borders. It shall be stressed that the implementation of the

2) The idea of solidary Poland refers to the concept of solidarity and the opposition movement of Solidarity collective action based on mutual support and strong social ties.
Westphalian state model by European powers led at that time to the disintegration of Poland at the end of the eighteenth century. The legal and political consolidation and centralization of the partition states within their borders resulted in a weakening of what had belonged to the Polish legacies. In the following decades, Polish territories were treated as a Prussian-Russian-Austrian borderland. However, centripetal tendencies (related to the consolidation of those states) boundarized (Jones 1959) the previously existing frontiers (KRISTOF 1959). Internal standardization within the three empires was visible in different economic models, language and cultural influences (Germanization and Russification policies), but also in the proliferation of specific political norms and values organizing public life in the three states, especially the principle of the rule of law in Germany, of tsarist autocracy (самодержавие) in Russia, and parliamentarianism in Austria. The Polish territories followed the development paths of their respective capitals.

Fifthly, in looking for explanations for the existence of phantom borders in contemporary Polish political life, researchers have proposed various models explaining the phenomenon. Two 
dimensions can be identified within those efforts: structural and normative ${ }^{3)}$. The former stresses objectively existing differences in economic development levels (higher in western and northern Poland, lower in central and eastern), economic models (industrial west versus rural east), infrastructural density, closeness to the western markets, and so on (ZARYCKI 2000). The latter pays attention to the norms and values dominating in various parts of Poland, and resulting from the nineteenth century political traditions of the powers occupying the Polish provinces (the German, Russian and Austrian Polands) as well as the displacement and re-settlement of the population after 1945 (in the case of the post-German provinces) (RACIBORSKI 1997). Those historical legacies were to contribute - in the interpretation of many political scientists - to different types of political culture in the four zones. The former is not the same as the latter, but forms the context for a specific type of development of political culture.

The author represents the norms and values oriented school in the above presented debate, and is of the opinion, that in trying to categorize political behavior in the four Polish zones, a classical approach of political culture may be academically useful. In this view - after SidNeY VERBA - political culture is "a system of empirical beliefs, symbols and values that define situation where political action takes place" (Verba 1965). Lucian Pye describes it as a "sum of the fundamental values, sentiments and knowledge that give form and substance to political process" (Pye 1995). Almond and Verba (1963) enumerated three types of political culture: parochial (low knowledge about the system and low involvement of individuals), subjective (individuals share knowledge and sensitivity towards the authorities' activities and the functioning of the system, however they still

3) This distinction is supplemented in the literature in the reflections on mutual relations between both approaches, linking structure and norms. For example, functionalist political theory stresses "nationalization" of a state's population by means of infrastructural linkages, but resulting in theories of indoctrination. Structural functionalism tries to relate one element of the social system to another (FISHER 2010, 75). In the structural approach, legal and constitutional elements are stressed, which is visible in the policies of the executive. In the normative vision "political culture and political norms constitute images that a state transmits" (Maoz and RussetT 1993, 625). Both explanations are considered not to be mutually exclusive, but rather present various facets of the investigated phenomenon (Maoz and Russett 1993, 625). remain passive) and participatory (consciousness is followed by involvement). They can all be identified in the presented zones. This will be the approach applied in this text.

Unfortunately, the limitations of this publication do not allow the author to discuss more widely either the development of the concept of political culture, or the literature on voting behavior. It is, however, relevant to stress at least the main tendencies in both research fields.

In the case of the concept of political culture, three phases in approaching the issue can be enumerated here (STREET 1993, 97). The one initiated by Almond and Verba (1963) (applied by the author) concentrated on civic culture and the link between individual's behavior and the functioning of the system. The second phase is constituted mainly by academic criticism and the development of the concept, seeing, among others, political culture not as a cause but as an effect of political processes, and stressing that the concept does not explain how it is created and how political socialization happens (STREET 1993, 100-101; BARRY 1978, 51-52). The third phase is the rediscovery of the concept in the 1980s, widening the understanding of political culture, including, for example, emotions and beliefs that constitute specific meaning for political processes (Rose 1980), attitudes allowing interpretation of politics (STREET 1993, 103), or even popular culture. Individuals not only passively obtain ideas, they also select what they obtain depending on the context (BеEтHAм 1991). Still, however, those approaches stress the explanatory power of culture "in the way in which interests are identified and then acted upon" (STREET 1993, 113). This has been demonstrated by the enormous interest of researchers in political culture as a tool for explaining the transformation and democratization processes in Central and Eastern Europe after the collapse of communism, often using traditional approaches. The model of Almond and Verba "provides sufficiently universal tools to begin making sense of people's orientations toward political objects in Central and Eastern Europe" (Peтtai 2007, 92). Another question posed was if the old cultural patterns change rapidly under circumstances of transformation or rather tend to remain stable (BERNIK and Malnar 2003, 200-201).

The wide literature on voting behavior should also be mentioned here. Investigators try to extract determinants of how decisions in electoral activities are made, testing various factors. Simplifying the categorization it can be stated that at least two opposite grand schools are present in the debate: stress- 
ing the role of rationality and non-rational elements in voting behavior (NorRIs 2004, 6). The latter is the perspective where, among others, the concept of culture is researched, including political culture. The former is represented, for example, by rational choice institutionalism. Scholars of each of the schools (and often of both of them) test electoral behavior, concentrating on various factors, such as the influence of political information (HoBOLt 2005), formal rules (NorRIs 2004, 6), party, individual and issue orientation (CAMPBELL et al. 1954), social class or ethnic group belonging, previous electoral activity (Green and Shachar 2000), and many others.

Finally, a remark has to be made, linking the above discussed phenomenon of electoral preferences and the concept of political culture. The question is whether the historical legacies bring not only various levels of participatory political culture, but also a more plural political culture? This is in fact the question of whether culture defines the environment, or if it also leads to clear voting preferences? This issue could be solved by comparing not only the winners or the strongest party (as presented above) but more or less the whole 'palette' of political options that gain support in the given regions.

For example, when comparing the position of PiS in the Russian and Austrian Polands and PO and SLD in the German Poland and post-German territories, one can see an interesting regularity. Using the example of presidential elections in 2010, it can be noticed that in the first round Kaczyński got support of between $40 \%$ and $55 \%$ in the eastern and southern regions (getting over 50\% in one of them), and between $24 \%$ and $32 \%$ in the northern and western regions. Komorowski, in turn received between $29 \%$ and $37 \%$, and between $45 \%-52 \%$ (getting over $50 \%$ in three of them). The candidates of other parties and committees (there were 10 altogether) attracted the support of about only $1 \%-2 \%$ per candidate, with exception of the SLD candidate who gained almost $14 \%$. His votes were concentrated in German Poland and the post-German territories (Fig. 2 a). This reveals the more pluralistic political culture in those regions, with a clearly liberal profile, and an openness, with a wider spectrum of candidates. In Russian and Austrian Polands the culture is less pluralistic, with more polarized political preferences.

The parliamentary elections reveal a similar pattern (Fig. 2b). In 2007, PO dominated in the North and West, with support of between $45 \%$ and $58 \%$ (counted at the level of electoral constituencies) and PiS won in the rest of Poland, gaining between 35\% and $51 \%$ of the votes. Only two other parties got the support higher than $1.5 \%$, the alliance of left-wing parties got over 13\%, mainly in German Poland and the post-German territories, PSL mainly in the other regions. The elections in 2011 confirmed these regularities.

Those two examples more open up this aspect of investigation than allows the author to formulate clear conclusions. They definitely show once again the existence of phantom borders, visible in various forms of pluralistic political culture. PO is essen-
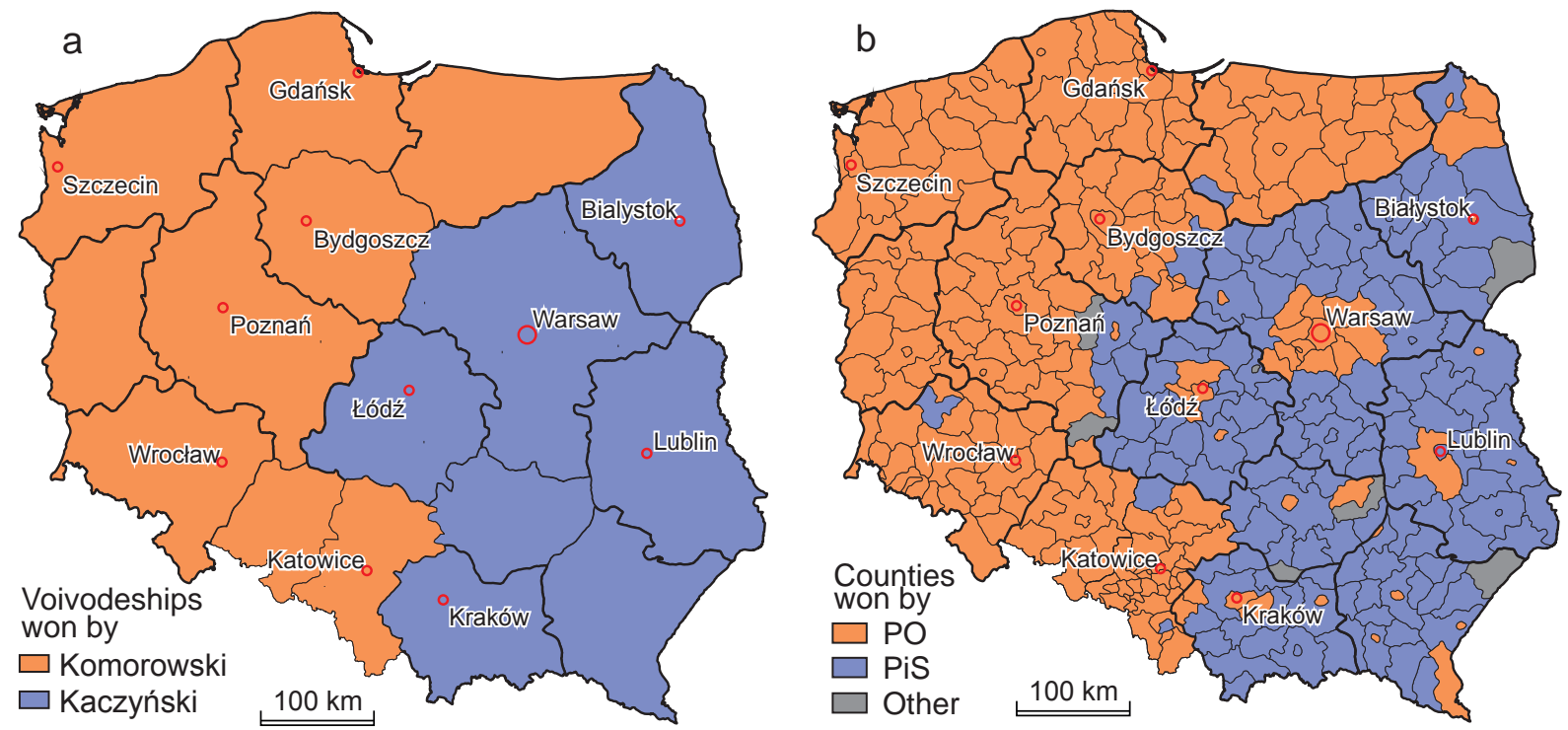

Fig. 2: Results of the presidential elections 2010 (a) and the parliamentary elections 2007 (b) 
tially stronger in the North and West than PiS in the East and South, but on the other hand, the former competes there with stronger competitors than the latter in their own areas of domination.

\section{The sample: Pomorskie Region and Wielkopolskie Region}

The above described tendencies in electoral behavior are usually related to the regional scale (in practice, the macro-scale), where the borders of regions often correspond with the phantom borders in Poland. However, an empirical look shows that this is not always so. There are some cases where historical divisions cut through homogeneous administrative units (Fig. 1.). Two regions: Pomorze and Wielkopolska represent the case.

Both the Pomorskie and Wielkopolskie Regions (see Fig.1 and in detail Fig. 3) are ancestors of the regional traditions of the first and second Polish republics. They existed then as administrative units with very specific economic, cultural and linguistic profiles. Both were incorporated in the Prussian/ German state. Both were granted regional self-governance in the interwar period (which was the case of only three Polish regions at that time). Both were reduced in terms of territory during the communist period and finally reconstructed in something approaching their historical spatial forms as a result of the 1999 administrative reform aiming at decentralization. Finally, both are populated by communities sharing a strong regional identity, based on both historic legacies and current developments, and sometimes characterized by a feeling of superiority over other Polish provinces, especially those in the east.

Today's Pomorskie Region is inhabited by about $2.2 \mathrm{mln}$ residents, who are concentrated in the metropolitan area of Gdańsk (Danzig), Gdynia and Sopot, the Vistula River valley and the city (in Polish miasto) of Słupsk. It is administratively divided into 20 counties and 4 cities. The region is dynamically developing, based on both maritime industries and services, as well as on tourism and education (Strategia).

In terms of the most recent history, the Pomorskie region consists of three parts (Fig. 3: the central strip (forming a part of the Polish state in the interwar period, and being Slavic at that time, inhabited by an ethnic group of Kashubians), no. a, the Free City of Gdańsk (an independent city governed by the league of Nations and mainly ethnically German by 1945), and two parts in the eastern and western parts of the region (belonging to the German state by the end of the Second World War and ethnically German), no. b. As a consequence of the war, and then the Potsdam Conference, the German population fled and was expelled (Piskorski 2013), the empty spaces in the region were re-inhabited with Polish settlers mainly expelled from the former eastern Polish provinces that were transferred to the Soviet Union (Nitschke 1999). Consequently the central part of the region represents Polish/Kashubian traditions of a long-residential character, strongly influenced by nineteenth century Prussian/German political and cultural legacies. The western and eastern parts share a migratory character and are rooted in the eastern Polish type of politics and culture.

The Wielkopolskie Region has 3.4 million inhabitants, concentrated mainly in the metropolitan area of Poznań, and then around other bigger cities (Leszno, Konin, Piła, Kalisz). The region consists of 35 counties (including 4 cities). The economy of the region is based on industry and services located mainly in the metropolitan areas, as well as on agriculture, also making it one of the most developed Polish regions.

The actual region consists of three parts: the main one (belonging in the nineteenth century to the German state, but ethnically Polish at that time, no. $x$ ), the eastern outskirts (belonging in the nineteenth century to the Russian state but also ethnically Polish, no. y) and northern parts (by 1945 a part of the German state and by then ethnically German, no. z). Consequently, in the first: Polish legacies with German influences dominate, in the second: Polish traditions influenced by Russian legacies, and in the third: Polish resettlement traditions (related to the post-Second World War expulsion and resettlements).

\section{The regions during parliamentary and presidential elections}

The starting point for empirical investigation into political behavior is the central elections and the macro-level. In parliamentary and presidential elections, the political behaviors of the investigated regions inhabitants reveal the existence of phantom borders. Analyses locate both Pomorze and Wielkopolska in liberal Poland, characterized by relatively high turnout and anti-conservative attitudes. Those two features can be comparably confronted with the Polish central and eastern provinces, where participation levels are lower and anti-liberal ten- 


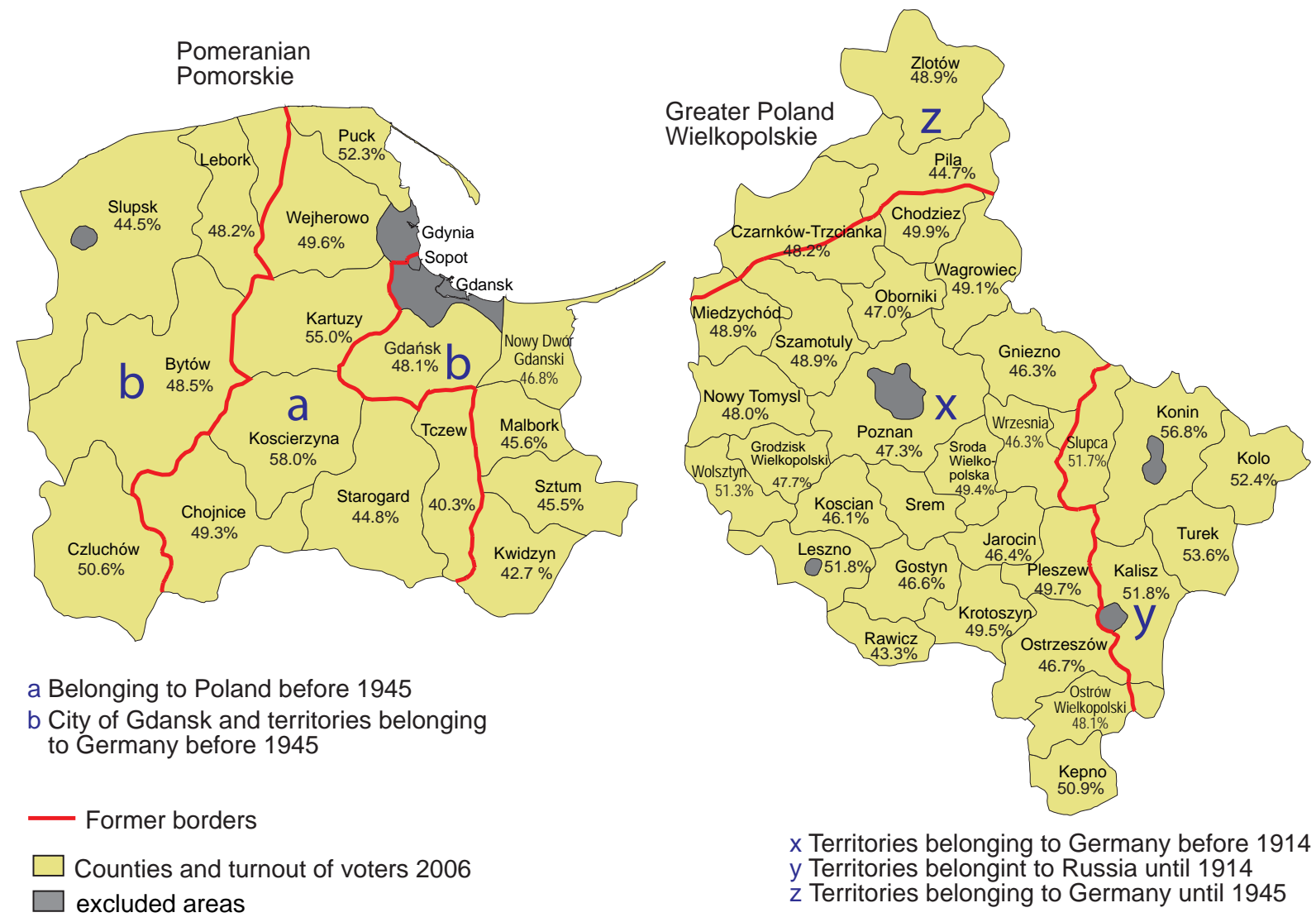

Fig. 3: Phantom borders in the Pomorskie and Wielkopolskie Regions and voter turnout in the 2006 local elections at county level. Data source: Self-Government Elections 2006 and JAŃCZAK et al. 2013

dencies stronger. Political scientists tend to explain this phenomenon by the political culture dominating in both regions and resulting from nineteenth century Prussian/German influences. It is claimed that belonging to the Prussian/German state created participative attitudes (contrary to parochial ones in the provinces under Russian rule) and openness towards western values.

The political profile of the regions in parliamentary election reveals the more liberal character and higher voting participation in these regions than in the Poland-wide results (Tab. 1). Both SLD and $\mathrm{PO}$ gained more votes than average in both regions while turnout has always been higher than elsewhere.

The same tendency has been visible in the case of presidential elections (Tab. 2). Turnout is higher than the Polish average and liberal candidates (Donald Tusk, Bronisław Komorowski) collect more votes than in the central and eastern regions of Poland, where Lech and then Jarosław Kaczyński collected the majority of their votes.

\subsection{Step one: territorial downscaling}

However, still looking at parliamentary and presidential elections, when reducing the scale of the analyses and replacing region-average indicators with a county level comparison, both regions are no longer homogeneous in terms of their political behavior and political preferences. Phantom borders, reflecting the German, Russian and population replacement legacies, are visible in both participation levels and political preferences. In the case of Pomorze, turnout is higher in the central part (representing Prussian/German legacies and more participative political culture) and lower in the western and eastern parts (re-settlement territories, with populations representing more parochial traditions). Similarly in Wielkopolska the eastern parts (Russian legacies) have been characterized by lower participation than the rest of the region. Also, the winning party or candidate varies locally. In Wielkopolska in 2005 PO won on the regional scale. However, in the eastern outskirts it was the SLD the collected 
Tab. 1: Parliamentary elections in Poland, Pomorskie and Wielkopolskie Regions

\begin{tabular}{|c|c|c|c|c|c|c|c|c|}
\hline & \multicolumn{2}{|c|}{2001} & \multicolumn{2}{|c|}{2005} & \multicolumn{2}{|c|}{2007} & \multicolumn{2}{|c|}{2011} \\
\hline & Winner & Turnout & Winner & Turnout & Winner & Turnout & Winner & Turnout \\
\hline Poland & SLD $41 \%$ & $46 \%$ & PiS 27\% & $40 \%$ & PO $41 \%$ & $54 \%$ & PO $39 \%$ & $49 \%$ \\
\hline Pomorskie & SLD 36\% & $47 \%$ & PO $40 \%$ & $43 \%$ & PO $55 \%$ & $57 \%$ & PO $62 \%$ & $52 \%$ \\
\hline Wielkopolskie & SLD $46 \%$ & $50 \%$ & PO $38 \%$ & $41 \%$ & Po $44 \%$ & $55 \%$ & PO $55 \%$ & $55 \%$ \\
\hline
\end{tabular}

Tab. 2: Presidential elections in Poland, Pomorskie and Wielkopolskie Regions

\begin{tabular}{|c|c|c|c|c|c|c|c|c|}
\hline & \multicolumn{2}{|c|}{$2005(1)$} & \multicolumn{2}{|c|}{$2005(2)$} & \multicolumn{2}{|c|}{$2010(1)$} & \multicolumn{2}{|c|}{ 2010(2) } \\
\hline & Winner & Turnout & Winner & Turnout & Winner & Turnout & Winner & Turnout \\
\hline Poland & Tusk $36 \%$ & $50 \%$ & Kacz 54\% & $51 \%$ & Kom 41\% & $55 \%$ & Kom 53\% & $55 \%$ \\
\hline Pomorskie & Tusk $49 \%$ & $54 \%$ & Tusk 57\% & $55 \%$ & Kom 52\% & $58 \%$ & Kom $65 \%$ & $59 \%$ \\
\hline Wielkopolskie & Tusk $41 \%$ & $51 \%$ & Tusk 52\% & $51 \%$ & Kom $47 \%$ & $56 \%$ & Kom $61 \%$ & $54 \%$ \\
\hline
\end{tabular}

Source: The author (following National Electoral Commission, Państwowa Komisja Wyborcza, http://pkw.gov.pl, visited: 01.02.2014)

the biggest share of votes. Similarly, in the following elections, the east of the region revealed much higher support for PiS than the rest of the province, where it was very rarely chosen. In Pomorze the support for Tusk and Komorowski in the presidential elections was lowest in the central strip of the region. In Wielkopolska, Kaczyński won in the eastern counties, Komorowski in the rest of the region.

The picture that can be drawn when investigating the regions is that in the case of state-level voting (parliamentary and presidential), phantom borders mark historical divisions. Prussian/German Poland (the central strip of Pomorze and most of Wielkopolska) seems to represent a participative political culture, visible in the high turnout, whereas Russian and re-settlement Poland (eastern Wielkopolska and western and eastern parts of Pomorze) is dominated by more passive attitudes. At the same time, political preferences vary.

\subsection{Step two: electoral downscaling}

The question is, then, if the described phenomenon is also confirmed by other types of voting, such as local elections. If a political culture based on historical legacies determines participation levels and political preferences, they should be similarly visible also when testing other types of elections. This would mean at the same time a second de-scaling of the analyses. Not only does the scale of ter- ritorial units need to be reduced (from the regional to sub-regional level), but also the election type is downgraded by checking non-central voting.

This methodological shift is based on the rich "scale research" literature, which, due to the form of this text, cannot be elaborated on further, (however it is widely debated by KaISER and NiKIFOROWA 2008, 538-541). The opinion seems to dominate in the literature recently that "the scale of analysis is not naturally determined, but represents a social construct" (Kolossov 2005, 628). It is, however, important to notice that the state of art recognizes "scale [as] an active progenitor of specific social processes" (Sмith 1992) and assumes scales to be "arenas around which sociospatial power choreographies are enacted and performed" (SwYNGEDOuW 2004). Research into scale in recent years has additionally brought a shift in analytical focus. Initially, they were "socially constructed as the actors that matter," now it is usually considered "a category of practice performed by actors/actants" (KAISER and Nikiforowa 2008, 541).

In the further investigation, the county-level local government elections were employed as a test of the presented phenomenon, and the elections in 2002, 2006, 2010 and 2014 were compared (National Electoral Commission).

Both turnout and winning political options were investigated, as reflecting participation levels and political preferences. To meet the methodological postulate of comparability, only similar territo- 
rial units were compared. It was thus decided to eliminate the metropolises and leave the town-rural counties in the sample.

With regard to the turnout, phantom borders were again noticeable. In 2002 turnout nationally reached a level of $49 \%$, while in Pomorskie it was $50 \%$, in Wielkopolskie - 49\%. In Pomorze the highest participation was noted in Kartuski and Kościerski counties $(59 \%$ and $58 \%$ ) in the very core of the central strip. In Kwidzyński and Malborski in the east, it was about $15 \%$ lower (46\% and $43 \%$ ), in Słupski and Chojnicki in the west, about 10\% lower (49\% in both). In the central and northern parts of Wielkopolska, the turnout was about $48 \%$. In the eastern counties however it was on average $6 \%$ higher - in Koniński 57\%, in Kolski 53\%! Consequently in Pomorze, the Prussian/German participative legacies were visible in the central strip, while the resettlement eastern and western outskirts were more passive. In Wielkopolska, the Russian legacies in the eastern counties represented - surprisingly - more participative attitudes than the central part with Prussian/German traditions. This contradicts the previous interpretation based on elements of participative and parochial political culture on both sides of the former border.

In 2006 the national turnout was at the level of $46 \%$, while in both Pomorskie and Wielkopolskie it was $47 \%$. In the former, again, in the central counties participation was about $10 \%$ higher, in the western and eastern ones about 5\% lower. In the latter - also similarly to the previous election - the eastern counties represented on average 7\% higher involvement, than the rest of the province (Fig. 3). In 2010 the national turnout reached the level of $50 \%$ and $49 \%$ in both investigated regions. Local differences again revealed similar patterns. Similarly to the elections in 2014.

Political preferences also reflected phantom borders' existence. In 2002 in Pomorskie, the majority of the competing committees pretended to have a local character, however many had, in fact, central affiliation, being linked to national political parties and organizations. In the central strip, however, local Kashubian organizations received strong support (Kaszubskie Zrzeszenie Wyborcze or Samorzadne Kaszuby - Naszé Sprawë). SLD (ruling at that time in Poland) won the support of $20 \%-37 \%$ of voters in the western and eastern parts of the region and only about $15 \%$ in the central strip. In Wielkopolska, SLD gained roughly equal support of about one third of voters in all parts of the region and won the elections.
In 2006 the central authorities were dominated by $\mathrm{PiS}$ - it was the main component of the parliamentary majority and of the central government. In Pomorze again the western and eastern parts supported SLD and additionally Samoobrona (a radical rural party). In the central strip PiS, PO and local committees dominated the scene. In Wielkopolska, again left wing and liberal committees dominated, regardless of the part of the region. At the same time, only in the east did Samoobrona gain significant support (about 15\%) and PiS collected almost no support (4\% in comparison to $15 \%-20 \%$ in the other counties of the region).

In 2010 PO was in power at the central level. In Pomorskie, PO dominated in the central strip, in two counties winning an absolute majority of seats in the councils, local committees were also still strongly supported. In the west and east of the region the SLD achieved a relatively good result. In Wielkopolska, PO dominated in the central part of the region, the SLD and peasant parties in the eastern parts, where - by contrast - the liberals achieved a relatively weak result.

In 2014, it was still PO who ruled at the central level, however, its position was weakening. In Pomorskie, the tendency from previous years was visible, especially with regard to the local committees in the central strip and the significant position of PO, but also PiS being much stronger (often the winning power) in the eastern and western outskirts, replacing SLD's domination. In Wielkopolskie, PSL won the elections in almost all the counties, but in the east PiS was visibly the second power.

\section{Interpretation}

The above presented quantitative evidence demonstrates the existence of phantom borders in Poland. A double de-scaling investigation, however, revealed that, despite the relatively stable location of the lines separating the historical legacies and political cultures, electoral behavior (especially the participation level) is manifested differently at various levels of political life. Participative and parochial types seem to explain well the regional differences in central elections. But in the local level elections, different patterns can be also detected, which calls for further interpretation.

With regard to participation levels, the case of phantom borders in Pomorze seems to be similarly constructed in both scales. But the reason why the eastern (representing Russian Poland legacies) outskirts 
of Wielkopolska are more passive then the rest in parliamentary or presidential elections and more active in local elections requires explaining.

Interviews conducted in the eastern counties suggest an interesting explanation. Local leaders stress feelings of subordination and worseness in relation to Wielkopolska proper. It is considered to be dynamic, well organized, representing German order. Consequently, it is admired and copied in the eastern counties. Local territorial units and populations tend to confirm their belonging to the province and desire to overcome, in their own eyes, the economic and political handicaps in this way. They try to deconstruct the old border and overcome otherization from the main part of Wielkopolska. This can be achieved by shifting the phantom border to the eastern boundary of the current Wielkopolskie Region. This also reveals the basic function of the border - to separate in this case, from the other Russian Poland provinces. One of the tools to achieve this aim is to exercise the rules and norms that are assigned to Wielkopolska and adopt the German political traditions. This recalls the neophyte syndrome, understood as being new to the environment and consequently experiencing the necessity of never-ending confirmation of one's own belonging and loyalty to be entirely and finally accepted. ${ }^{4)}$ Participation in elections is one of the indicators of being a part of participative culture. However, central elections are differently perceived than local ones. The former belong to national political realities and are considered to be of exogenic nature. Local elections are reported to be something with a regional, endogenic character.

Why, then, is the same mechanism not visible in the case of the western and eastern counties of Pomorze? As narrated by local elites, the central strip is also positively regarded, but as something alien, and at the same time unachievable. First, due to the resettlement tradition (contrary to the situation in Wielkopolska), second due to the ethnic situation and the Kashubian character of the territory. Borders - also phantom borders - are "self-perpetuating and resistant to change" (Newman 2003) in this case. Regional unity is realistic when based on a common national standard and only political norms and val-

4) This explanation requires, however, further research, this time by upscaling the perspective and applying the comparative approach to the other territorial units located further in the east. A high level of participation in local elections is observable there as well, which cannot be explained with the same argumentation. ues need to be adjusted across phantom borders. This cannot be the aim if historical legacies correspond with linguistic and ethnic peculiarities. The location, manifestation and re-construction of phantom borders remains an empirical reality.

Electoral preferences show fewer scale-related features. When - at the county level polls - Prussian/ German Poland opts mainly for liberals (similarly to the central elections), Russian Poland and post-German Poland are much more open to socially oriented parties, sometimes of populist character. This can be the conservative PiS but also the social democratic SLD or even the radical rural Samoobrona party. Political culture can serve again as a convincing explanation, revealing a less mature type of political orientation. More cohesive attitudes in inter-scale comparison suggest, however, the necessity of further research. They should also include structurally oriented elements.

\section{Conclusions}

The presented investigation reveals several peculiarities of phantom borders in Wielkopolska and Pomorze but also of the phantom borders themselves. Electoral borders resulting from historical legacies have consequences for actual political and social divisions. Historical spaces are reproduced in various ways in current electoral behavior. It is visible both on the macro and micro scale, however the pattern of political behavior does not remain exactly the same. Phantom borders are located in the same place in both scales. But double de-scaling (territorial and electoral) shows that political participation is variously constructed on both scales. In the macro perspective elements of parochial political culture in Russian and post-German (re-settlement) Poland result in lower turnout, compared to the Prussian/ German Poland's participative political culture (revealed in higher participation). In the doubly reduced scale in Wielkopolska this rule is reversed as an element of relict border deconstruction and an attempt to shift it to the eastern outskirts of the region. It serves to find similarities on one side and differences on the other. Consequently, the inhabitants of the Russian part of Wielkopolska use phantom borders as tools for self-inclusion to the region proper and marking the more easterly territories as others, enclosing the region with a sharp historical-political legacy. In Pomorze this is impossible, so the line is maintained. The ethnic peculiarity of the Kashubian population makes any changes impossible, so scale change re- 
sults in confirming not only the relict border's location, but also the stable character of political behavior it separates. Those findings on political behavior on respective sides of a former border are not only an empirical discovery, but also bring consequences for the concept of phantom borders. They reveal that scale manipulation can serve as a methodological tool to better explain the nature of phantom borders.

Finally, the presented considerations open up space for further investigation at the same time. Among other things, there are questions of whether the aforementioned phantomization is conducted consciously or not by the actors involved, how present it is in the political discourse of politicians, and to what extent the historical interpretations of spatial factors shape their electoral strategies. And finally, whether the two investigated cases reflect processes that can be generalized and applicable to the other regions in Poland.

\section{References}

Alkan, N. (2002): Borders in Europe. In: Alkan, N. (ed.): Borders of Europe. Bonn, 31-71.

Almond, G. and Verba, S. (1963): The civic culture: political attitudes and democracy in five nations. Princeton, NJ.

BARry, B. (1978): Sociologists, economists and democracy. Chicago.

Bartkowski, J. (2002): Tradycja i polityka. Wpływ tradycji kulturowych polskich regionów na współczesne zachowania społeczne i polityczne. Warszawa.

Bernik, I. and Malnar, B. (2003): Political culture in postcommuist Europe: radical cultural chance of adaptation on the basis of old cultural patterns". In: PolLACK, D.; Jacobs, J.; Mueller, O. and Pickel, G. (eds.): Political culture in post-communist Europe. Aldershot, 181-205.

Beetham, D. (1991): The legitimation of power. Basingstoke.

BoAs, T. C. (2007): Conceptualizing continuity and change. The composite-standard model of path dependence. In: Journal of Theoretical Politics 19, 33-54. DOI: 10.1177/0951629807071016

Brunet-JAilly, E. (2005): Theorizing borders: an interdisciplinary perspective. In: Geopolitics 10, 633-649. DOI: 10.1080/14650040500318449

Campbell, A.; Gurin, G. and Miller, W. E. (1954): The voter decides. Oxford.

Donaj, L. (2013): Platforma jak „Kolejorz” - ciagle w czołówce tabeli, ale ... rewelacja sezonu to to nie jest... In: Alberski, R.; Cichosz, M. and Kobielska, K. (eds.): Gra o regiony. Wybory do sejmików województw w 2010. Wrocław, 83-103.
Ehlers, N.; Buursink, J. and Boekema, F. (2001): Introduction. Binational cities and their regions: from diverging cases to a common research agenda. In: GeoJournal 54, 1-5. DOI: 10.1023/A:1021132212768

FisHER, J. R. (2010): System theory and structural functionalism. In: Ishiyama, J. T. and Breuning, M. (eds.): $21^{\text {st }}$ century political science. A reference handbook. Los Angeles, London, New Dehli, Singapore, Washington DC, 71-80.

Green, D. P. and Shachar, R. (2000): Habit formation and political behaviour: evidence of consuetude in voter turnout. In: British Journal of Political Science 30, $561-573$.

Grygo, B. and SEcler, B. (2010): Blokowanie list, (nie)skuteczny sposób na zwycięstwo PiS. Wybory do sejmiku województwa w Wielkopolsce. In: Alberski, R.; CIchosz, M. and Tomczak, Ł. (eds.): Wybory do sejmików województw w 2006 roku. Wrocław, 239-250.

Hовоцт, S. B. (2005): When Europe matters: the impact of political information on voting behaviour in EU referendums. In: Journal of Elections, Public Opinion and Parties 15, 85-109. DOI: 10.1080/13689880500064635

JAŃCZAK, J. (2010): Walka w mateczniku Solidarności. Wybory do sejmiku województwa pomorskiego In: ALBERSKI, R.; Cichosz, M. and TomczaK, L. (eds.): Wybory do sejmików województw w 2006 roku. Wrocław, 179-189.

- (2013): Na Północy (prawie) bez zmian. Wybory do sejmiku województwa pomorskiego. In: Alberski, R.; Cichosz, M. and Kobielska K. (eds.): Gra o regiony. Wybory do sejmików województw w 2010. Wrocław, 203-217.

Jańczak, J.; Musial-Karg, M. and Secler, B. (2013): Wybory samorządowe na ziemi lubuskiej, Pomorzu i w Wielkopolsce. Granice historyczne i relacje centra-peryferia a zachowania wyborcze. Torun.

JANicki, M.; WŁadyKA, W. and ZAGNER, A. (2005): Wybory jak rozbiory. In: Polityka 44, 6-12.

Jones, S. B. (1959): Boundary concepts in the setting of place and time. In: Annals of the Association of American Geographers 49, 241-255. DOI: 10.1111/j.14678306.1959.tb01611.x

Kaiser, R. and Nikiforova, E. (2008): The performativity of scale: the social construction of scale effects in Narva, Estonia. In: Environment and Planning D: Society and Space 26, 537-562. DOI: 10.1068/d3307

Kolossov, V. (2005): Theorizing borders. Border studies: changing perspectives and theoretical approaches. In: Geopolitics 10, 606-632. DOI: 101080/14650040500318415

Kristof, L. K. D. (1959): The nature of frontiers and boundaries. In: Annals of the Association of American Geographers 49, 269-285. DOI: 10.1111/j.14678306.1959.tb01613.x 
Maoz, Z. and Russett, B. (1993): Normative and structural causes of democratic peace, 1946-1986. In: The American Political Science Review 87, 624-638.

NATIONAL ELECTORAL COMMISSION OF THE REPUBLIC OF POLAND. http://www.pkw.gov.pl (Date: 23.01.2014)

Newman, D. (2003): On borders and power: a theoretical framework. In: Journal of Borderland Studies 18, 13-25. DOI: $10.1080 / 08865655.2003 .9695598$

NitschKe, B. (1999): Wysiedlenia ludności niemieckiej z Polski w latach 1945-1949. Zielona Góra.

Norris, P. (2004): Electoral engineering. Voting rules and electoral behavior. Cambridge.

O’Dowd, L. and Wilson, T. (2002): Frontiers of sovereignty in the new Europe. In: Alkan, N. (ed.): Borders of Europe. Bonn, 7-30.

PAasi, A. (2005): Generations and the 'development' of border studies. In: Geopolitics 10, 663-671. DOI: 10.1080/14650040500318563

Page, S. E. (2006): Path dependence. In: Quarterly Journal of Political Science 1, 87-115.

PAYAN, T. (2014): Theory-building in border studies: the view from North America. In: Eurasia Border Review 5, 1-18.

Peters, B. G; Pierre, J. and King, D. S. (2005): The politics of path dependency: political conflict in historical institutionalism. In: The Journal of Politics 67, 1275-1300. DOI: 10.1111/j.1468-2508.2005.00360.x

Pettai, V. (2007): Studying political culture in post-communist Europe. In: Schartau, M.-B.; Berglund, S. and Henningsen, B. (eds.): Political culture. Values and identities in the Baltic Sea Region. Berlin, 83-95.

Phantomgrenzen in Ostmitteleuropa. http://www.phantomgrenzen.eu (Date: 20.03.2014)

PIskorski, J. M. (2013): Die Verjagten. Flucht und Vertreibung in Europa des 20. Jahrhunderts. München.

Pye, L. (1995): Political culture. In: LiPset, S. (ed.): The encyclopedia of democracy. London, New York, 965-969.

RACIBORSKI, J. (1997): Polskie wybory. Zachowania wyborcze społeczeństwa polskiego w latach 1998-1995. Warszawa.

Rose, R. (1980): Politics in England. An Interpretation for the 1980s. London.

Self-Government Elections 2010. National Electoral Commission of the Republic of Poland. http://wybory2010. pkw.gov.pl/att/1/pl/000000.html\#tabs-1 (Date: 23.01.2014)

Smith, N. (1992): Geography, difference and the politics of scale. In: Doherty J.; Graham E. and Malek, M. (eds.): Postmodernism and the social science. New York, 57-79.

Strategia Rozwoju Województwa Pomorskiego, Załącznik do Uchwały nr 587/XXXV/05 Sejmiku Województwa Pomorskiego z dnia 18 lipca 2005 roku w sprawie przyjęcia Strategii Rozwoju Województwa Pomorskiego.
Street, J. (1993): Political culture - from civic culture to the mass culture. In: British Journal of Political Science 24, 95-114. DOI: 10.1017/S0007123400006803

Swyngedouw, E. (2004): Scaled geographies: nature place and the politics of scale. In: SHeppard, E. and McMasTER, R. (eds.): Scale and geographic inquiry. Oxford, 129-153.

VERBA, S. (1965): Conclusion: comparative political culture. In: Pye, L. and Verba, S. (eds.): Political culture and political development. Princeton, 512-560.

ZARYCKI, T. (2000): O niektórych dylematach współczesnych badań nad przestrzenia społeczną. In: Studia Regionalne i Lokalne 4, 5-22.

\author{
Author \\ Dr Jarosław Jańczak \\ Adam Mickiewicz University \\ Faculty of Political Science \\ and Journalism \\ ul. Umultowska 89a, \\ 61-614 Poznań, \\ Poland \\ jaroslaw.janczak@amu.edu.pl
}

